\title{
Synthesis of Isomaltooligosaccharides (IMOs) from Sweet Potato Starch by Simultaneous Saccharification and Transglycosylation Using Saccharomyces cerevisiae Var. diastaticus BE 134 to Improve Purity of IMOs
}

\author{
Quan Duong Hong $\mathbb{D}^{1,2}$ Tri Hoang Minh $\mathbb{D}^{2},{ }^{2}$ Hong Gam Nguyen Thi, \\ Thu Hien Nguyen Thi, ${ }^{2}$ Ngoc Hoa Nguyen, ${ }^{1}$ Truc Lam Nguyen Thi, ${ }^{1}$ Van Anh Nguyen Thi, \\ Thu Trang Vu $\left(\mathbb{D},{ }^{2}\right.$ and Hong Nga Luong $\mathbb{D}^{2}$ \\ ${ }^{1}$ Ho Chi Minh City University of Food Industry (HUFI), 140 Le Trong Tan Street, Tay Thanh Ward, Tan Phu District, \\ Ho Chi Minh City, Vietnam \\ ${ }^{2}$ School of Biotechnology and Food Technology, Hanoi University of Science and Technology, No. 1, Dai Co Viet Street, \\ Hai Ba Trung District, Hanoi, Vietnam
}

Correspondence should be addressed to Quan Duong Hong; quandh@hufi.edu.vn, Tri Hoang Minh; hoangminhtri99@gmail.com, Thu Trang Vu; trang.vuthu@hust.edu.vn, and Hong Nga Luong; nga.luonghong@hust.edu.vn

Received 10 August 2021; Revised 10 September 2021; Accepted 13 September 2021; Published 28 September 2021

Academic Editor: Chunpeng Wan

Copyright (C 2021 Quan Duong Hong et al. This is an open access article distributed under the Creative Commons Attribution License, which permits unrestricted use, distribution, and reproduction in any medium, provided the original work is properly cited.

\begin{abstract}
This study developed a simple two-step procedure to produce isomaltooligosaccharides (IMOs) from low-cost sweet potato starch (SPS). Effect of various reaction parameters on the steps of the synthesis process of IMOs was systematically investigated. The results show that Spezyme Xtra enzyme was the most suitable for the liquefaction step. The oligosaccharide components' contents, including $\mathrm{G}_{1}-\mathrm{G}_{10}$ and $\mathrm{G}_{2}-\mathrm{G}_{6}$, reached $73.95 \pm 0.02 \%$ and $49.24 \pm 3.19 \%$, respectively, after liquefaction. The simultaneous saccharification and transglycosylation (SST) reaction of SPS followed the liquefaction after the $\alpha$-amylase activity was deactivated. This reaction was simultaneously treated by $\beta$-amylase, pullulanase, and $\alpha$-transglucosidase. The effect of various reaction parameters, consisting of solution $\mathrm{pH}$, reaction temperature, enzyme dosage, and reaction time, on the SST reaction to synthesize IMOs from SPS was fully studied. The results showed that the highest concentration of $\left.\mathrm{IMOs}_{(\mathrm{IG}} \mathrm{IG}_{23}\right)$ reached $68.85 \pm 1.82 \mathrm{~g} / \mathrm{L}$ at the optimal condition. The purification of pristine IMO was performed by adding Saccharomyces cerevisiae var. diastaticus BE 134 yeast cells at the final step of the procedure. In particular, the SST reaction for the synthesis of IMOs from SPS shortened SST reaction time by three times compared with other three-step synthesis procedures of IMOs. These findings show that the SPSderived IMOs can be applied as a novel and inexpensive prebiotic healthcare product for human gastrointestinal health, dieters, and diabetics.
\end{abstract}

\section{Introduction}

Isomaltooligosaccharides (IMOs) are glucosyl saccharides containing one or more $\alpha$-1,6-glycosidic linkages with or without $\alpha$-1,4-glycosidic linkages [1]. The commercial IMO syrup is generally accepted as a mixture of glucosyl saccharides with both $\alpha$-1,6-glycosidic linkages and $\alpha$-1,4glycosidic linkages in its constituent $[2,3]$. The structure of
IMOs is characterized by their polymerization degree (DP) (from 2 to 10$)$, linkages types ( $\alpha-1-2,3,4$, or 6-glycosidic), and the proportion as well as position of each type of linkage [4]. The degree of polymerization and the ratio between $\alpha$-1,4-glycosidic linking and other bonds are important factors determining the ability to digest and metabolize IMOs by intestinal microflora $[5,6]$. The most abundant and well-recognized functional components in the IMOs are 
isomaltose $/ \alpha$-D-Glc $p$ - $(1 \longrightarrow 6)-\alpha$-D-Glc $p \quad\left(\mathrm{IG}_{2}\right), \quad$ iso-

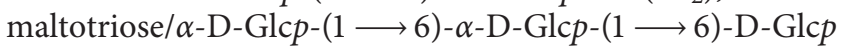
$\left(\mathrm{IG}_{3}\right)$, and isomaltotetraose $/ \alpha-\mathrm{D}-\mathrm{Gl} c p-(1 \longrightarrow 6)-(\alpha-\mathrm{D}-\mathrm{Gl} c p-$ $(1 \longrightarrow 6))_{2}$-D-Glcp $\left(\mathrm{IG}_{4}\right)$, which have been collectively abbreviated as $\mathrm{IG}_{234}$ [3]. The recent studies reported that the main constituents found in commercial IMOs consisted of isomaltose $\left(\mathrm{IG}_{2}\right)$, panose, isomaltotriose $\left(\mathrm{IG}_{3}\right)$, and isomaltotetraose $\left(\mathrm{IG}_{4}\right)$ [7]. This may be related to the ability of transglucosidase enzyme derived from Aspergillus niger mainly existent on short-chain oligosaccharide substrates $[1,8]$. Specifically, Niu et al. [4] calculated the formed IMOs concentration synthesizing from enzyme cocktail based on obtained sum of concentrations of all $\mathrm{IG}_{2}, \mathrm{IG}_{3}$, and panose. Also, Cui et al. [7] also computed IMOs concentration extracted from Chinese chestnut starch by total concentrations of $\mathrm{IG}_{2}, \mathrm{IG}_{3}$, and panose. The IMOs total concentration obtained from banana flour was sum of both $\mathrm{IG}_{3}$ and $\mathrm{IG}_{4}[9]$.

The IMOs are the potential prebiotics to help improve the beneficial microflora in the body. For example, the Bifidobacteria in the feces were found to significantly increase when human applied IMOs derived from different sources [10-13], as well as increasing reproduction of Lactobacilli $[10,11]$ while inhibiting nonbeneficial bacteria such as Clostridium perfringens in both mice and human intestinal tracts [10] when the IMOs were used. On the other hand, E. coli and other pathogenic bacteria could not metabolize IMOs [14]. The IMOs have been shown to have a low glycemic index [15,16] and anticonstipation effects [17] and reduced amount of cholesterol in the blood.

Most commercial IMOs have been enzymatically produced from a wide range of starches through transglycosyl action [3]. The conventional synthesis of IMOs from starch is involved in a three-step procedure of liquefaction, saccharification, and transglycosidation in separation. Firstly, the starch is decomposed into $\alpha$ - $(1,4)$-linked $\alpha$-D-glucooligosaccharides using $\alpha$-amylase, pullulanase, and $\beta$-amylase. In the next step, the $\alpha$ - $(1,4)$-linked $\alpha$-Dglucooligosaccharides continue to be converted into $\alpha$ - $(1,6)$ linked oligosaccharides using $\alpha$-transglucosidase [18]. Then, in the transglycosidation step, transglucosidase usually carries out two tasks: (1) the hydrolysis of $\alpha$-D-glucooligosaccharides and (2) transfer of the glucosyl group to $6-\mathrm{OH}$ of glucose. At the end of process, beside the desirable products of isomaltose and panose which are formed from the transglycosidation of glucosyl to D-glucose and maltose, respectively, the process also generates a large amount of glucose and $\alpha$ - $(1,4)$ oligomers (mainly maltose) as byproducts $[7,19]$. These impure by-products need to be removed from obtained IMO products. The transglucosidase was reported to be present in various fungi, such as Aspergillus niger [1], Aureobasidium pullulans [20], Aspergillus carbonarius [21], Thermoanaerobacter thermocopriae [22], and Aspergillus nidulans [23]. However, the transglucosidase was extracted from these types of fungi for low purity of IMOs. Moreover, the neopullulanase in Bacillus subtilis [24] was reported to contain function of a- $(1,6)$-transglycosylation which can combine with $\alpha$-amylase for the synthesis of high-purity IMOs from starch. Improved efficiencies of IMO synthesis have been reported by enzymes combination used in the manufacturing process. The action of simultaneous catalysis by $\alpha$-amylase and BE followed by simultaneous $\beta$-amylase and $\alpha$-transglucosidase using cassava starch as substrate liberated high contents of isomaltose, isomaltotriose, and panose [25]. In addition, IMO and oligodextrans were also synthesized from sucrose using the enzymes dextransucrase and dextranase [26]. The coupling of Fungamyl and $\alpha$-transglucosidase improved productivity of IMO production and alleviated the inhibition of glucose to action of $\alpha$-glucosidase in transglycosylation step [27]. Therefore, the three kinds of $\beta$-amylase, pullulanase, and transglucosidase were simultaneously supplemented into SST reaction with desire to shorten time required for highest IMOs concentration in this study. The strategy was based on the combination of $\beta$-amylase and pullulanase for starch saccharification obtaining higher contents of maltose and maltotriose with low residual maltodextrins, which resulted in elevated levels of substrates for transglycosylation. At the same time, the presence of transglucosidase enzyme in the solution immediately resulted in transglycosylation and generated IMOs, in which $\alpha$-(1,6)-linkages are formed after transglycosylation that is not attacked by pullulanase because the products of IMO synthesis process do not meet the properties of the substrates of pullulanase [28]. In particular, in the final step of synthesis procedure of IMOs, the Saccharomyces cerevisiae var. diastaticus $\mathrm{BE} 134$ yeast cells were applied to eliminate undesirable sugars such as glucose, maltose, and maltotriose to improve further purity of obtained IMOs.

It is clear that a three-step synthesis procedure of IMOs from various starch sources exhibited many drawbacks due to consuming much time and cost for deactivation of enzymes activities and adjusting reaction parameters after the reactions were finished to be suitable with following reactions. Therefore, development of a two-step simple synthesis procedure of IMOs should be applied to overcome the aforementioned drawbacks of the three-step procedure.

Due to possessing many advantages, the studies to produce IMOs from various sources have gained increasing attention by scholars. Beside the IMOs that have been found in traditional products such as honey [29], miso [30], and sake [31], the IMOs have been produced from a wide variety of starch sources such as tapioca starch [25,32], corn starch [4], rice starch [1], banana starch [9], sugarcane plants [33], and chestnut starch [7].

The sweet potatoes are one of the most popular starch sources around the world. In particular, the sweet potatoes were grown all over agriculture land of Vietnam with abundant concentration and very cheap price. The Food and Agriculture Organization of the United Nations (FAO) reported that the amount of sweet potatoes which was produced in Vietnam in 2019 was about 1,402,350 tons, accounting for approximately $0.98 \%$ of the total world production [34]. In this study, the Hoang Long sweet potatoes grown in infertile soil of Bac Giang province where there is tropical monsoon climate with the annual average temperature, rainfall, and air humidity of $23.2^{\circ} \mathrm{C}-23.8^{\circ} \mathrm{C}$, $1400-1730 \mathrm{~mm}$, and 83 to $84 \%$, respectively, were used to 
produce IMOs. Besides, the main sweet potatoes' functional components were starches, vitamins, minerals, and amylose which have been proved as health-promoting functions [19]. These components are suitable for the production of IMOs. Hence, the sweet potato starch has potential as a quality raw material for production of IMOs. However, to the best of our knowledge, the production of IMOs from the sweet potatoes has not been investigated up to now, especially the production of IMOs from sweet potato starch by a two-step procedure using simultaneous saccharification and transglycosylation.

Therefore, the aim of this study was to synthesize the IMOs product derived from sweet potato starch as functional food ingredient for human gastrointestinal health, dieters, and diabetics. To reach this aim, a simple, inexpensive, and highly effective two-step synthesis procedure of IMOs from sweet potato starch was developed using the simultaneous saccharification and transglycosylation. Besides, effects of various reaction parameters, including kinds of enzyme preparation, enzyme dosages, solution $\mathrm{pH}$, reaction temperature, and reaction time, on the overall synthesis procedure of IMOs from SPS were systematically investigated to choose the optimal condition for production of IMOs. The obtained products of the synthesis procedure of IMOs were analyzed using HPLC-RID.

\section{Materials and Methods}

2.1. Materials and Reagents. Hoang Long sweet potatoes (Ipomoea batatas) were harvested from Viet Yen district, Bac Giang province, Vietnam. Liquozyme SC DS and Termamyl SC DS enzyme preparations were obtained from Novozymes (Denmark), while Spezyme Alpha and Spezyme Xtra enzyme preparations were purchased from DuPont (USA); $\beta$-amylase was obtained from Barley, while transglucosidase enzyme from Aspergillus niger and pullulanase M2 from Bacillus licheniformis were purchased from Sigma-Aldrich (USA). Isomaltose $\left(\mathrm{IG}_{2}\right)$ and isomaltotriose $\left(\mathrm{IG}_{3}\right)$ were obtained from Megazyme (USA). Glucose $\left(G_{1}\right)$, maltose $\left(G_{2}\right)$, maltotriose $\left(G_{3}\right)$, maltotetraose $\left(G_{4}\right)$, maltopentaose $\left(G_{5}\right)$, maltohexaose $\left(G_{6}\right)$, maltoheptaose $\left(G_{7}\right)$, maltooctaose $\left(G_{8}\right)$, maltononaose $\left(G_{9}\right)$, and maltodecaose $\left(G_{10}\right)$ were purchased from Sigma-Aldrich (USA). Isomaltotetraose $\left(\mathrm{IG}_{4}\right)$ was obtained from TCI, Japan. All other reagents and chemicals were used as received without further purification.

Saccharomyces cerevisiae var. diastaticus BE 134 yeast cells were acquired from Fermentis by Lesaffre.

\subsection{Analytical Methods}

2.2.1. Total Carbohydrate Concentrations. Total carbohydrate concentrations were determined based on the study of Dubois et al. [35]. First, an exact amount of $10 \mathrm{mg}$ sample was transferred into test tube with simultaneously adding $0.2 \mathrm{~mL}$ of ethanol $\left(80^{\circ}\right)$ and $1.0 \mathrm{~mL}$ of DMSO $(90 \%)$ to the mixture. The test tube was then completely shaken to homogenate sample. Afterwards, the test tube was stood for $10 \mathrm{~min}$ at room temperature $\left(25 \pm 2^{\circ} \mathrm{C}\right)$. In the next step, a $2.0 \mathrm{~mL}$ of boiling double distilled water was supplemented into the test tube and boiled for $15 \mathrm{~min}$. The solution was then cooled down and distilled water was added until reaching exactly $10 \mathrm{~mL}$ of solution. The obtained solution was continuously diluted 10 times to achieve solution B. $1.0 \mathrm{~mL}$ of solution $\mathrm{B}$ was pipetted and transferred into the test tube. Simultaneously, $1.0 \mathrm{~mL}$ of phenol and $5.0 \mathrm{~mL}$ of concentrated $\mathrm{H}_{2} \mathrm{SO}_{4}$ were added to this test tube. The reaction that occurred in this test tube was maintained for 20 min of contact time. The solution was finally analyzed by UV-Vis spectrophotometer (photoLab 6600, Germany) at $\lambda=490 \mathrm{~nm}$ for determination of total carbohydrate concentrations.

2.2.2. $\alpha$-Amylase Assay. Amylase activity of $\alpha$-amylase preparation was determined according to Ceralpha method which was instructed by Megazyme [36]. The principle of the method is based on hydrolysis of nonreducing-end blocked p-nitrophenyl maltoheptaoside (BPNPG7) by $\alpha$-amylase to form p-nitrophenyl maltosaccharide. After that, $\alpha$-glucosidase presence in solution was activated to participle this hydrolysis reaction to form glucose and free p-nitrophenol. At the end of reaction, reaction solution would turn into yellow color. Finally, the p-nitrophenol was determined based on standard coefficient [36].

In this study, the procedure for assay of $\alpha$-amylase was performed as follows: firstly, a $0.2 \mathrm{~mL}$ of BPNPG7 substrate was transferred into test tube and preincubated at $40^{\circ} \mathrm{C}$ for $5 \mathrm{~min}$. In parallel, the diluted $\alpha$-amylase HR reagent solution (unbuffered) was also preincubated at $40^{\circ} \mathrm{C}$ for $5 \mathrm{~min}$. In the next step, an above preincubated $0.2 \mathrm{~mL}$ of the diluted $\alpha$-amylase preparation was directly added to the bottom of the test tube containing BPNPG7 substrate. The test tube was continuously incubated at $40^{\circ} \mathrm{C}$ for exactly $10 \mathrm{~min}$. At the end of the $10 \mathrm{~min}$ incubation period, an exact amount of $3.0 \mathrm{~mL}$ of stopping reagent was supplemented in the mixture and vigorously shaken in test tube. Finally, the result solution and blank sample were measured using UV-Vis spectrophotometer (photoLab 6600, Germany) at $\lambda=400 \mathrm{~nm}$. One enzyme activity unit is defined as the amount of enzyme, in the presence of excess thermostable $\alpha$-glucosidase, required to release one micromole of p-nitrophenol from BPNPG7 in one minute under the defined assay conditions. The activity unit is termed as Ceralpha Unit (CU).

2.2.3. $\beta$-Amylase Assay. $\beta$-Amylase activity was determined according to betamyl-3 method [37]. Firstly, the betamyl-3 substrate (PNP $\beta-G 3)$ solution was preincubated at $40^{\circ} \mathrm{C}$ for approximately $5 \mathrm{~min}$. At the same time, $0.2 \mathrm{~mL}$ of diluted enzyme solution was transferred into test tube and preincubated at $40^{\circ} \mathrm{C}$ for approximately $5 \mathrm{~min}$. In each test tube containing diluted enzyme, $0.2 \mathrm{~mL}$ of PNP $\beta$-G3 was supplemented. The tube was then shaken completely and incubated at $40^{\circ} \mathrm{C}$ for exactly $10 \mathrm{~min}$. At the end of the $10 \mathrm{~min}$ incubation period, $3.0 \mathrm{~mL}$ of stopping reagent was added to the test tube and stirred vigorously to reach homogenous mixture. Finally, the result mixture and blank sample were measured using UV-Vis spectrophotometer (photoLab 
6600 , Germany) at $\lambda=400 \mathrm{~nm}$. One unit of enzyme activity is defined as the amount of the enzyme $\beta$-amylase required to release 1 micromole of $p$-nitrophenol from $\mathrm{PNP} \beta$-G3 per 1 min under the defined assay conditions, and it is termed as betamyl-3 unit. The conversion from betamyl-3 activity units to IU units was followed according to Megazyme's instructions.

2.2.4. Pullulanase Assay. The principle of pullulanase analysis method is followed by Megazyme's instructions [38]. In this study, to analyze pullulanase, firstly, both pullulanase and Red Rullulan substrate were preequilibrated at $40^{\circ} \mathrm{C}$ for $5 \mathrm{~min}$. Then, add $1.0 \mathrm{~mL}$ preequilibrated enzyme solution to $0.5 \mathrm{~mL}$ of preequilibrated Red Pullulan solution. Stir the mixture and incubate at $40^{\circ} \mathrm{C}$ for exactly $10 \mathrm{~min}$. Stop the reaction by adding $2.5 \mathrm{~mL}$ of ethanol $(95 \% \mathrm{v} / \mathrm{v})$ and shaking vigorously for 10 seconds. Allow the reaction tubes to equilibrate at room temperature for $10 \mathrm{~min}$. The tube was centrifuged at $1000 \mathrm{~g}$ for $10 \mathrm{~min}$ and the supernatant was collected to measure pullulanase activity at $\lambda=510 \mathrm{~nm}$. The blank sample was prepared by adding ethanol to the Red Pullulan substrate before adding the enzyme. The activity of pullulanase is determined by reference to the standard curve (provided by [38]).

2.2.5. Transglucosidase Assay. Transglucosidase activity was determined using maltose as substrate which was adapted from the previous study [27]. The transglucosidase enzyme was incubated with $1 \%(\mathrm{w} / \mathrm{w})$ maltose solution at $40^{\circ} \mathrm{C}$ in $0.5 \mathrm{mM}$ sodium acetate buffer $(\mathrm{pH} 4.0)$ for 15 minutes. The reaction was stopped by boiling the mixture for $10 \mathrm{~min}$. The amount of released glucose was measured using GOD-POD kit (Megazyme). One unit of enzyme activity is defined as the amount of the enzyme that produces $1 \mu \mathrm{mol}$ of glucose per minute under the aforementioned conditions.

2.3. Preparation of Sweet Potato Starch. The sweet potato starch (SPS) was prepared from fresh tubers immediately after harvest. First, the sweet potatoes were cleaned with water several times to remove dirt. Next, the sweet potatoes were cut into small sheets using knife and ground by blender. The ground sweet potatoes were then sifted through 60,100 , and 200-mesh sieves to obtain pure starch. The residue was removed. The solution containing starch was then left to settle for 6 hours. The resulting solution was decanted to gain pure starch and remove water as well as impurities on the surface of the settled starch. Settling process was repeated 3 times. Finally, wet starch was obtained and dried at $40^{\circ} \mathrm{C}$ until its humidity reached about $10 \%$. The starch extraction rate was $11.58 \%$ calculated on fresh weight basis. The products were stored in plastic bags at $4^{\circ} \mathrm{C}$ for next experiments.

2.4. Synthesis Procedure of IMOs from Sweet Potato Starch. The synthesis procedure of IMOs from sweet potatoes is illustrated in Figure 1.
Processing of IMOs from sweet potatoes is described in detail as follows.

2.4.1. Liquefaction. Firstly, the dried sweet potato starch (SPS) was dissolved in acetate buffer at $\mathrm{pH}$ of 5.8 to reach $25 \%(\mathrm{w} / \mathrm{v})$ of starch slurry. In the next step, four enzyme preparations of Spezyme Xtra, Spezyme Alpha, Termamyl SC DS, and Liquozyme SC DS were separately supplemented into reactor with content of each enzyme of $1.0 \mathrm{CU} / \mathrm{g}$ dried SPS. The reactor was maintained about $80-85^{\circ} \mathrm{C}$ for $30 \mathrm{~min}$ reaction time. At the end of liquefaction reaction, lactic acid was added to reactor to adjust solution $\mathrm{pH}$ to 3 . A total of $1.0 \mathrm{~mL}$ of the liquefied fluid was taken out to measure OS components at interval time of $30 \mathrm{~min}$ using HPLC-RID.

2.4.2. Simultaneous Saccharification and Transglycosylation. After liquefaction, the liquefied mixture was adjusted to $\mathrm{pH}$ of 5 by $\mathrm{NaOH} 5 \mathrm{~N}$. $3.0 \mathrm{U} / \mathrm{g} \beta$-amylase, $0.8 \mathrm{U} / \mathrm{g}$ pullulanase, and $10.0 \mathrm{U} / \mathrm{g}$ transglucosidase were then added to the mixture simultaneously. The mixture was vigorously shaken at $50^{\circ} \mathrm{C}$ for $12 \mathrm{~h}$. The sample was withdrawn after $12 \mathrm{~h}$ for determination of types and contents of the sugar components. The types and contents of the sugar components in the sample, including $\mathrm{IG}_{2}-\mathrm{IG}_{4}$, were determined using HPLCRID. Stopping the reaction was performed by boiling the mixture for $10 \mathrm{~min}$.

2.4.3. Purification of IMOs from Sweet Potato Starch. Because the IMOs product obtained from the simultaneous saccharification and transglycosylation (SST) step by $\beta$-amylase, pullulanase, and $\alpha$-transglucosidase contained undesirable sugar components such as glucose, maltose, and maltotriose, it is necessary to remove these undesirable byproducts. In this study, Saccharomyces cerevisiae var. diastaticus BE 134 yeast cells were applied for the removal of these undesirable sugars. Yeast cells after being obtained from Fermentis by Lesaffre were activated at $28^{\circ} \mathrm{C}$ for $15 \mathrm{~min}$. In the next step, the yeast cells were added to the test tube containing IMOs solution with cells densities of Saccharomyces cerevisiae var. diastaticus $\mathrm{BE} 134$ of $2 \times 10^{8}$ cells $/ \mathrm{mL}$ [1]. Then, the test tube was thermally stabilized at $28^{\circ} \mathrm{C}$. Afterwards, a $1.0 \mathrm{~mL}$ of sample in this test tube was taken every $12 \mathrm{~h}$. The test tube was then heated to $95^{\circ} \mathrm{C}$ for $10 \mathrm{~min}$ to kill all yeast cells. The mixture was centrifuged at $10000 \mathrm{~g}$ for $15 \mathrm{~min}$ to remove dead yeast cells and the supernatant was collected to qualitatively determine the undesirable sugars content using Thin-Layer Chromatography (TLC). At the point of reaction time when contents of glucose, maltose, and maltotriose are used up by yeast cells, the resulting samples solution is used to quantify IMOs concentration by HPLC-RID.

\subsection{Experiment Design}

2.5.1. The Experiment to Investigate the Effect of Various $\alpha$-Amylase Enzyme Preparations on the Liquefaction. The experiment aims to find out the most suitable $\alpha$-amylase for 


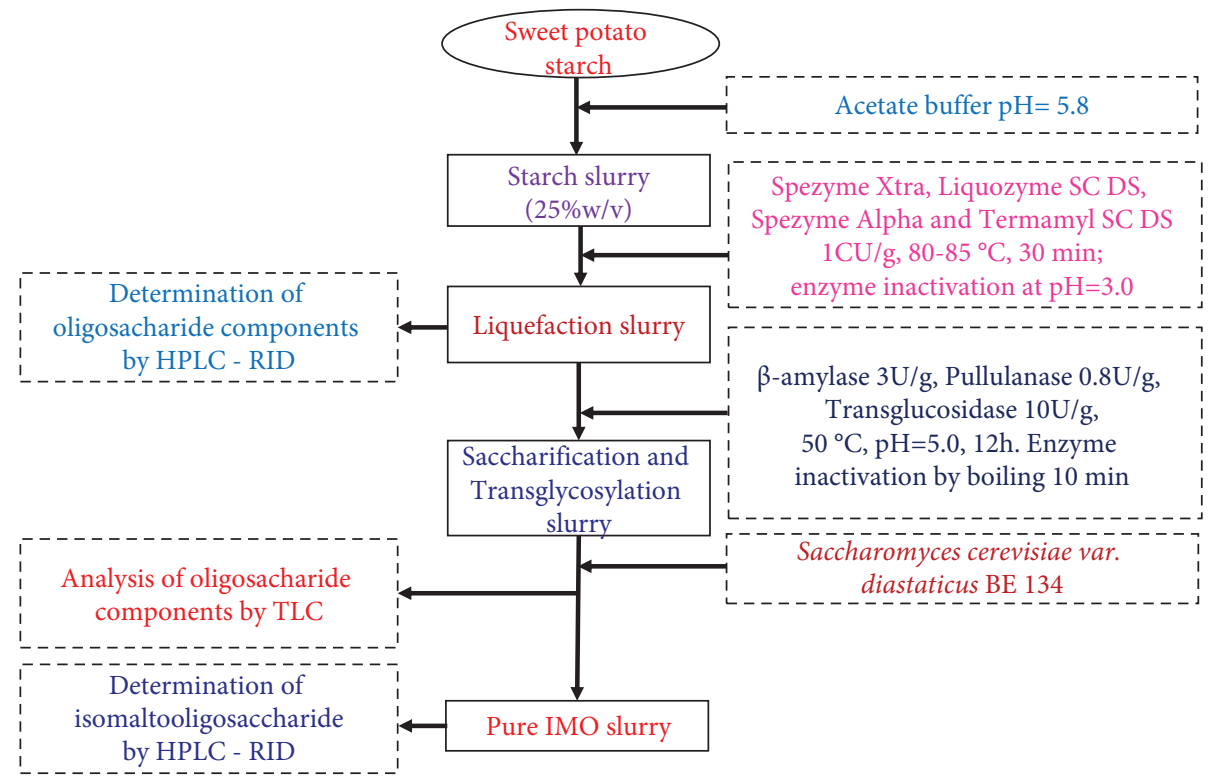

Figure 1: Processing isomaltooligosaccharides from sweet potatoes.

liquefaction reaction based on determining formed oligosaccharide components after hydrolysis by Spezyme Xtra, Liquozyme SC DS, Spezyme Alpha, and Termamyl SC DS enzyme preparations.

In this experiment, 8.571 grams of SPS with moisture of $12.5 \%$ was transferred into a $50 \mathrm{~mL}$ Falcol tube. Then, a sodium acetate buffer ( $\mathrm{pH}$ 5.8) was added to this Falcon tube to reach the final concentration of suspension sample of $25 \%$ $(\mathrm{w} / \mathrm{v})$ with the total volume of $30 \mathrm{~mL}$. The $\alpha$-amylase preparation was supplemented into the mixture with a content of $1 \mathrm{CU} / \mathrm{g}$ dried SPS. The mixture was heated for $25 \mathrm{~min}$. The reaction temperature was maintained at $80^{\circ} \mathrm{C}$ for the mixture with Spezyme Xtra and Liquozyme SC DS and at $85^{\circ} \mathrm{C}$ for reaction with Spezyme Alpha and Termamyl SC DS. After 30 min of reaction time, the enzyme was immediately deactivated by concentrated lactic acid at $\mathrm{pH}$ of 3.0. Finally, the obtained mixture after the liquefaction was diluted to the suitable concentration with double distilled water to determine the oligosaccharides contents by HPLC-RID and the residual starch content by the phenol-sulfuric acid method.

2.5.2. The Experiment to Investigate the Effect of Various Reaction Parameters on SST. The reaction parameters affecting the simultaneous saccharification and transglycosylation (SST) included solution $\mathrm{pH}$, temperature, enzyme dosages of $\beta$-amylase, pullulanase, and transglucosidase, and reaction time.

For the experiment to study effect of solution $\mathrm{pH}$ on the SST, the reaction was conducted by varying of $\mathrm{pH}$ values between 4.0, 4.5, 5.0, and 5.5. Meanwhile, the reaction temperature was fixed at $50^{\circ} \mathrm{C}$, and enzyme dosages of $\beta$-amylase, pullulanase, and transglucosidase were $3.0 \mathrm{U} / \mathrm{g}$, $0.8 \mathrm{U} / \mathrm{g}$, and $15.0 \mathrm{U} / \mathrm{g}$, respectively, during 12 hours of reaction time.

Towards the experiment to investigate effect of reaction temperature on the SST, the reaction parameters were fixed, including the enzyme dosages of $\beta$-amylase, pullulanase, and transglucosidase of $3.0 \mathrm{U} / \mathrm{g}, 0.8 \mathrm{U} / \mathrm{g}$, and $15.0 \mathrm{U} / \mathrm{g}$, respectively, at the optimal solution $\mathrm{pH}$ value obtained from the aforementioned experiment. Meanwhile the reaction temperature was varied between $45,50,55,60,65$, and $70^{\circ} \mathrm{C}$.

The experiment for studying effect of $\beta$-amylase dosage on the SST was carried out with varying of $\beta$-amylase dosages of $1 \mathrm{U} / \mathrm{g}, 2 \mathrm{U} / \mathrm{g}, 3 \mathrm{U} / \mathrm{g}, 4 \mathrm{U} / \mathrm{g}$, and $5 \mathrm{U} / \mathrm{g}$. The dosages of pullulanase and transglucosidase were fixed at $0.6 \mathrm{U} / \mathrm{g}$ and $15 \mathrm{U} / \mathrm{g}$, respectively. For the experiment to study effect of pullulanase dosage, the pullulanase dosages were changed in range of $0.2 \mathrm{U} / \mathrm{g}, 0.4 \mathrm{U} / \mathrm{g}, 0.6 \mathrm{U} / \mathrm{g}, 0.8 \mathrm{U} / \mathrm{g}$, and $1 \mathrm{U} / \mathrm{g}$ with simultaneously adding the optimal dosage of $\beta$-amylase obtained from aforementioned experiment and a transglucosidase dosage of $15 \mathrm{U} / \mathrm{g}$. Finally, the experiment for investigation of effect of transglucosidase dosage was conducted by fixing both optimal dosages of $\beta$-amylase and pullulanase which were gained from above experiments with varying of transglucosidase dosages of $3 \mathrm{U} / \mathrm{g}, 5 \mathrm{U} / \mathrm{g}, 10 \mathrm{U} / \mathrm{g}$, $15 \mathrm{U} / \mathrm{g}, 20 \mathrm{U} / \mathrm{g}, 25 \mathrm{U} / \mathrm{g}$, and $30 \mathrm{U} / \mathrm{g}$. All reactions conducted in the experiment to investigate effects of various enzymes on the STT were maintained at optimal $\mathrm{pH}$ value and temperature which were achieved from above experiments. At the end of reaction point, the enzymes were deactivated by boiling the mixture for $10 \mathrm{~min}$. Next, all undesirable sugars contained in post-STT solution were removed using Saccharomyces cerevisiae var. diastaticus BE 134 according to procedure as described in Section 2.4.3. The posttreated mixture was then used to determine the IMO's constituents using HPLC-RID.

The experiment to investigate effect of reaction time on the SST for synthesis of IMOs was performed by varying of reaction time from $6 \mathrm{~h}$ to $48 \mathrm{~h}$. The other operational parameters including optimal solution $\mathrm{pH}$, reaction temperature, and dosages of different enzymes which were obtained from the aforementioned experiments were fixed in this reaction. 
2.6. Analysis of Reaction Products. In this study, the undesirable sugar components in experiment to purify IMOs using Saccharomyces cerevisiae var. diastaticus BE 134 yeast cells were qualitatively determined using Thin-Layer Chromatography (TLC) method. The obtained results are presented in Figure S1 (in Supplementary Materials). The details of the TLC method used in this study were adapted from [39]. A $1.0 \mu \mathrm{L}$ sample and standard samples containing glucose, maltose, maltotriose, isomaltose (IMO2), and isomaltotriose (IMO3) were spotted on the silica gel 60 chromatoplates F254 $(20 \mathrm{~cm} \times 20 \mathrm{~cm}$; Merck KGaA, Germany) by a pipette with a distance of $10 \mathrm{~mm}$ from bottom to top. The distance between the spotting points on the chromatoplates was $10 \mathrm{~mm}$. The spotting points on the chromatoplates were then dried to maintain their sizes in range from 3 to $4 \mathrm{~mm}$. Afterwards, the chromatoplates were impregnated into mixture of solvent consisting of n-butanol: isopropanol: water at ratio of $50: 25: 20(\mathrm{v} / \mathrm{v} /$ v) in a TLC developing tank. Herein, the solvents and oligosaccharides are moved upwards by capillary force. The difference in interaction force between solvents, oligosaccharides compositions, and thin layer is the principle to determine the oligosaccharides components in this sample.

At the end of process, the chromatoplate was dried under room temperature $\left(25 \pm 2^{\circ} \mathrm{C}\right)$. To observe the oligosaccharide components, the chromatoplate was immersed into ethanol solution containing $5.0 \mathrm{~g} / \mathrm{L}$ of $\alpha$-naphthol and $50 \mathrm{~mL} / \mathrm{L} \mathrm{H}_{2} \mathrm{SO}_{4}$. Finally, the chromatoplate was taken out and dried under hot air at $120^{\circ} \mathrm{C}$ for $10 \mathrm{~min}$.

The oligosaccharides and IMOs compositions were quantitatively analyzed by HPLC using an RID detector. The HPLC-RID system (HPLC 1290-Agilent) was used with HyperREZ XP analysis column and carbohydrate $\mathrm{Na}^{+}$ $(7.7 \times 300 \mathrm{~mm})$ with guard column corresponding to HyperREZ XP and carbohydrate $\mathrm{Na}+(7.7 \times 50 \mathrm{~mm})$ obtained from Thermo Scientific, USA. Oligosaccharide standards include glucose $\left(G_{1}\right)$, maltose $\left(G_{2}\right)$, maltotriose $\left(G_{3}\right)$, maltotetraose $\left(G_{4}\right)$, maltopentaose $\left(G_{5}\right)$, maltohexaose $\left(G_{6}\right)$, maltoheptaose $\left(G_{7}\right)$, maltooctaose $\left(G_{8}\right)$, maltononaose $\left(\mathrm{G}_{9}\right)$, and maltodecaose $\left(\mathrm{G}_{10}\right)$.

Isomaltooligosaccharide standards include isomaltose $\left(\mathrm{IG}_{2}\right)$, isomaltotriose $\left(\mathrm{IG}_{3}\right)$, and isomaltotetraose $\left(\mathrm{IG}_{4}\right)$. Mobile phase is deionized water $(100 \%)$ with the flow rate of $0.05 \mathrm{~mL} / \mathrm{min}$. The column temperature was $25^{\circ} \mathrm{C}$ and the injection volume of sample was $20 \mu \mathrm{L}$.

All raw HPLC graphs of IMOs obtained at various experiment conditions are presented in Figures S2-S5 in Supplementary Materials.

2.7. Statistical Analysis. All tests were performed in duplicate. The experimental data were presented as average value \pm standard deviation (SD). Analysis of variance was performed using Duncan's multiple-range test under Microsoft Excel 2010, Origin 19, and SPSS software. Significance was defined at $p<0.05$.

\section{Results and Discussion}

3.1. Effects of Various $\alpha$-Amylase Enzyme Preparations on the Liquefaction Process. The slurry of SPS with a ratio of $25 \%$ $(\mathrm{w} / \mathrm{v})$ was prepared and then used to synthesize IMOs by a series of enzymatic reactions, consisting of liquefaction and simultaneous saccharification and transglycosylation. The liquefaction reaction aims to choose $\alpha$-amylase enzyme preparation for the highest contents of oligosaccharides components, in which the content of $G_{2}$ to $G_{6}$ is more noticeable than the remaining oligosaccharides because these substrates increased in the formation of maltose and maltotriose and could be also used directly by transglucosidase enzyme in the next step. Thus, increasing the content of $G_{2}$ to $G_{6}$ shortens the simultaneous saccharification and transglycosylation time required for maximum concentrations of $\mathrm{IG}_{234}$. The contents of oligosaccharide components in liquefaction process of SPS with adding different $\alpha$-amylase enzyme preparations are presented in Table 1. The results in Table 1 show that using four different $\alpha$-amylase enzyme preparations leads to formation of different liquefaction ingredients. Hydrolysis of Spezyme Xtra preparation gave that the total oligosaccharides contents from $G_{1}$ to $G_{10}\left(G_{1}-G_{10}\right)$ and $G_{2}$ to $G_{6}\left(G_{2}-G_{6}\right)$ were highest at $73.95 \%$ and $49.24 \%$, respectively. However, preparations of Liquozyme SC DS, Termamyl SC DS, and Spezyme Alpha had contents of both $\mathrm{G}_{1}-\mathrm{G}_{10}$ and $\mathrm{G}_{2}-\mathrm{G}_{6}$ lower than those of Spezyme Xtra preparation. The contents of $\mathrm{G}_{1}-\mathrm{G}_{10}$ and $\mathrm{G}_{2}-\mathrm{G}_{6}$ were, respectively, $40.46-68.59 \%$ for Liquozyme SC DS, 34.32-65.70\% for Spezyme Alpha, and 39.56-69.02\% for Termamyl SC DS. From data in Table 1, as can be seen, the formed glucose content in liquefaction was relatively low, only from 0.0 to $1.68 \%$. Also, the amount of formed starch residue was relatively small and there was significant difference between the enzyme preparations, from $1.56 \%$ to $2.15 \%$.

The detailed contents of each oligosaccharide in the hydrolyzed solution with $\alpha$-amylase enzyme preparations are indicated in Figure 2. What stands out from data in Figure 2 is that content of $\mathrm{G}_{6}$ in liquefied solution by Spezyme Xtra reached $20.89 \%$ which was higher compared with Liquozyme SC DS, Spezyme Alpha, and Termamyl SC DS. To be specific, the content of $\mathrm{G}_{6}$ was $18.07 \mathrm{~g} / \mathrm{L}, 15.79 \mathrm{~g} / \mathrm{L}$, and $17.02 \mathrm{~g} / \mathrm{L}$, respectively, for Liquozyme SC DS, Spezyme Alpha, and Termamyl SC DS. However, amounts of $G_{2}, G_{3}$, and $G_{4}$ possessed similar trend for all four applied enzyme preparations in liquefaction. Meanwhile, the concentration of $\mathrm{G}_{5}$ formed when hydrolyzed by Spezyme Xtra $(11.82 \mathrm{~g} / \mathrm{L})$ was higher than those of other preparations $(5.85-7.86 \mathrm{~g} / \mathrm{L})$. Based on these detailed results, it is clear that hydrolysis properties of each enzyme preparation in liquefaction had distinct difference. The addition of Spezyme Xtra preparation to liquefaction reaction gave the highest concentration of oligosaccharides components without generation of a low amount of both free glucose and starch residue. Moreover, temperature for liquefaction reaction using Spezyme Xtra was $80^{\circ} \mathrm{C}$ which was lower than those of other preparations triggering energy saving for overall synthesis procedure of IMOs. In particular, the statistical analysis also shows that 
TABLe 1: Compositions of oligosaccharides after using various $\alpha$-amylase enzyme preparations for liquefaction.

\begin{tabular}{lcccc}
\hline Enzyme preparation & $\mathrm{G}_{1}-\mathrm{G}_{10}(\% \mathrm{w} / \mathrm{w})$ & $\mathrm{G}_{2}-\mathrm{G}_{6}(\% \mathrm{w} / \mathrm{w})$ & Glucose $\left(\mathrm{G}_{1}\right)(\% \mathrm{w} / \mathrm{w})$ & Starch residue $(\% \mathrm{w} / \mathrm{w})$ \\
\hline Spezyme Xtra & $73.95 \pm 0.02^{\mathrm{a}}$ & $49.24 \pm 3.19^{\mathrm{a}}$ & $0.00 \pm 0.00^{\mathrm{a}}$ & $1.98 \pm 0.08^{\mathrm{a}}$ \\
Liquozyme SC DS & $68.59 \pm 1.62^{\mathrm{b}}$ & $40.46 \pm 0.08^{\mathrm{c}}$ & $0.61 \pm 0.86^{\mathrm{bc}}$ & $2.15 \pm 0.05^{\mathrm{a}}$ \\
Spezyme alpha & $65.70 \pm 0.32^{\mathrm{b}}$ & $34.32 \pm 0.48^{\mathrm{b}}$ & $0.51 \pm 0.72^{\mathrm{bc}}$ & $1.64 \pm 0.01^{\mathrm{b}}$ \\
Termamyl SC DS & $69.02 \pm 2.91^{\mathrm{b}}$ & $39.56 \pm 1.37^{\mathrm{c}}$ & $1.68 \pm 0.03^{\mathrm{bc}}$ & $1.56 \pm 0.08^{\mathrm{b}}$ \\
\hline
\end{tabular}

Values are mean \pm standard deviation of duplicate analyses. Values followed by the same letter in the same column were not significantly different at $p=0.05$.

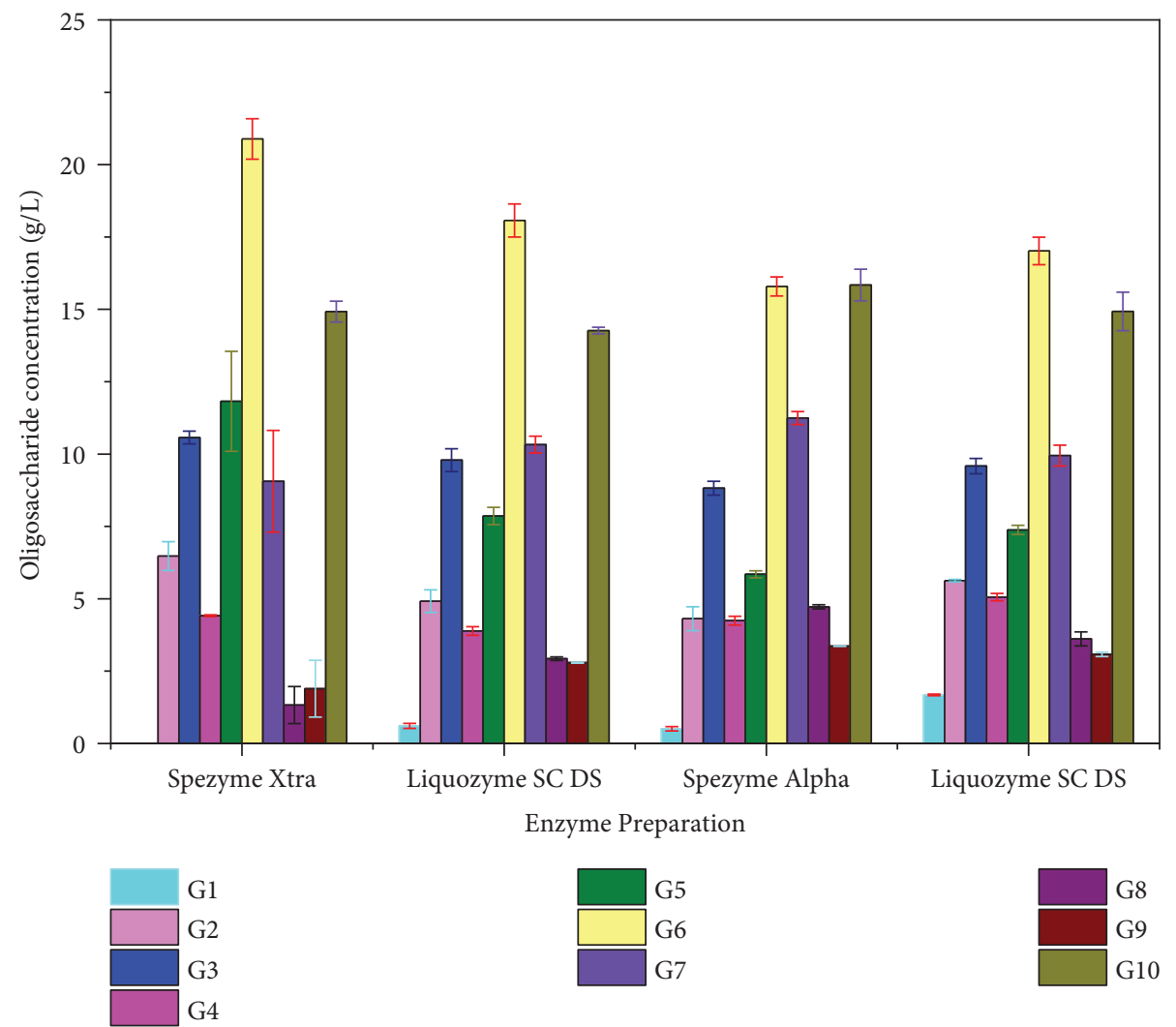

FIGURE 2: Oligosaccharide components in the liquefied mixture obtained after liquefaction using various $\alpha$-amylase enzyme preparations.

there was a significant difference between contents of oligosaccharides components, glucose, and starch residue when different enzyme preparations were supplemented into liquefaction reactions. Therefore, the Spezyme Xtra was chosen as the best enzyme preparation for the liquefaction of SPS in the synthesis procedure of IMOs.

\subsection{Effects of Solution $p H$ and Temperature on SST for the} Synthesis of IMOs. The solution $\mathrm{pH}$ and temperature are two important reaction parameters affecting the simultaneous saccharification and transglycosylation (SST) by $\beta$-amylase, pullulanase, and $\alpha$-transglucosidase for formation of IMOs from SPS. The results for investigation of effect of these parameters on the SST reaction for the synthesis of IMOs from SPS are illustrated in Figure 3.

During the SST reaction for synthesis of IMO, the enzymes of $\beta$-amylase and pullulanase were used to generate more maltose and other oligosaccharides which served as substrates for $\alpha$-transglucosidase to produce IMOs.
However, each enzyme exhibits a good activity at a certain $\mathrm{pH}$ and temperature. Namely, each kind of enzyme had an optimal $\mathrm{pH}$ and temperature value. In this study, the concentration of IMOs $\left(\mathrm{IG}_{234}\right)$ was calculated by the sum of $\mathrm{IG}_{2}$, $\mathrm{IG}_{3}$, and $\mathrm{IG}_{4}$ concentrations. Panose was not observed in this study because its amount gradually decreased until the end of transglycosylation caused by hydrolyzation and did not produce an important amount by $\alpha$-glucosidase (transglucosidase) $[3,32]$. Plot concentration of $\mathrm{IG}_{234}$ versus solution $\mathrm{pH}$ values (Figure 3(a)) and various reaction temperatures (Figure 3(b)) showed that concentration of IMOs $\left(\mathrm{IG}_{234}\right)$ strongly depended on the $\mathrm{pH}$ and temperature.

According to the manufacturer's description (Megazyme), the barley $\beta$-amylase, pullulanase M2 from Bacillus licheniformis, and transglucosidase from Aspergillus niger exhibiting their maximum activities at $\mathrm{pH}$ and temperature values were 6.0 and $60^{\circ} \mathrm{C}, 4.5-5.5$ and $55-60^{\circ} \mathrm{C}$, and 4.5 and $70^{\circ} \mathrm{C}$, respectively. Based on the data provided by manufacturer, the experiment to investigate effect of solution $\mathrm{pH}$ 


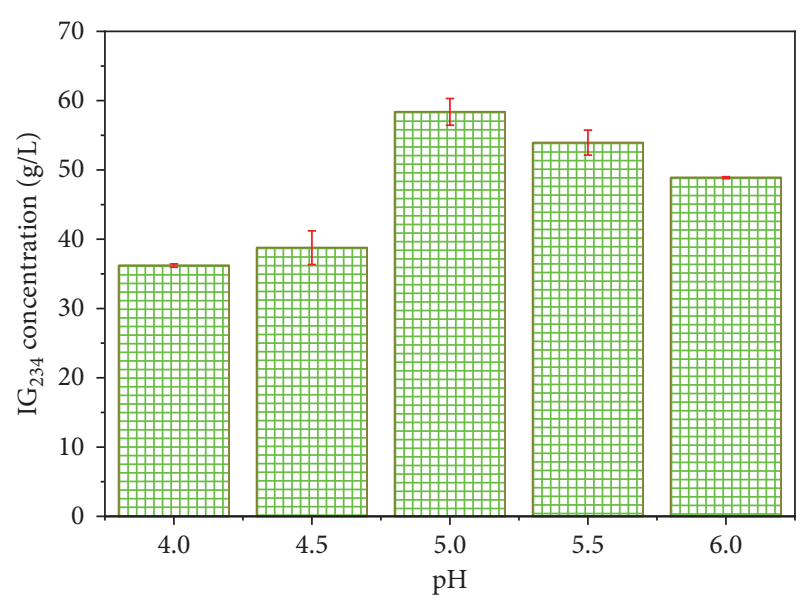

(a)

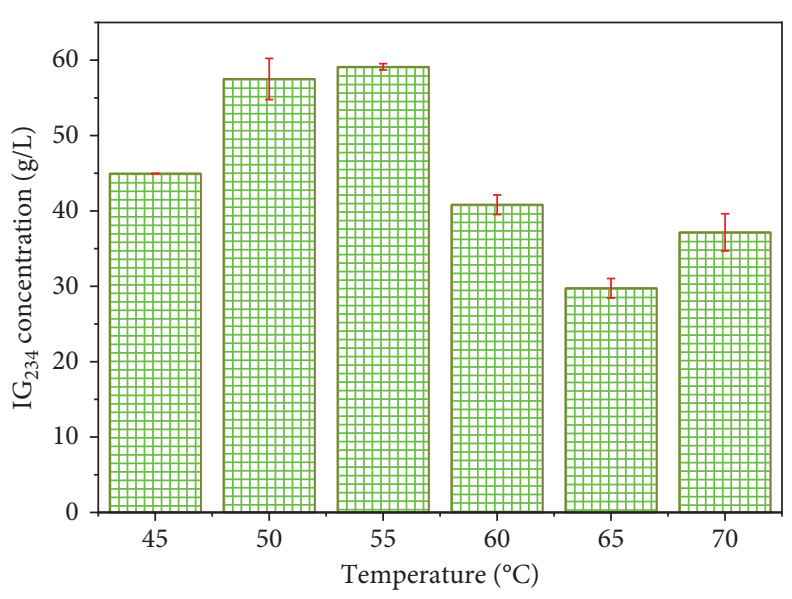

(b)

FIGURE 3: Effect of solution $\mathrm{pH}$ and reaction temperature on the formation of IMOs from SPS by SST.

in this study was performed with varying $\mathrm{pH}$ from 4.0 to 6.0 , adding the barley $\beta$-amylase, pullulanase, and transglucosidase to SST reaction at dosages of $3 \mathrm{U} / \mathrm{g}, 0.6 \mathrm{U} / \mathrm{g}$, and $15 \mathrm{U} / \mathrm{g}$, respectively, at $55^{\circ} \mathrm{C}$ for $12 \mathrm{~h}$ of reaction time. It can be seen from Figure 3(a) that there was an increase in concentration of $\mathrm{IG}_{234}$ when $\mathrm{pH}$ increased from 4.0 to 5.0. The maximum $\mathrm{IG}_{234}$ concentration was $58.39 \mathrm{~g} / \mathrm{L}$ at $\mathrm{pH}$ of 5.0 , while $\mathrm{pH}$ of 4.0 for concentration of $\mathrm{IG}_{234}$ was the lowest. When $\mathrm{pH}$ was further increased to 5.5 and 6.0 , the concentration of $\mathrm{IG}_{234}$ saw a slight downward trend. From these results, the most suitable $\mathrm{pH}$ value range for activation of all three enzymes that led to maximum concentration of $\mathrm{IG}_{234}$ was between 5.0 and 6.0. Also, the optimal $\mathrm{pH}$ value for SST reaction was chosen as 5.0 and this $\mathrm{pH}$ would be used for next experiments.

Figure 3(b) shows the effect of reaction temperatures on the formation of $\mathrm{IG}_{234}$ concentration from SPS by SST reaction. The concentration of $\mathrm{IG}_{234}$ witnessed an increase when the reaction temperatures were increased from 40 to $55^{\circ} \mathrm{C}$. The concentration of $\mathrm{IG}_{234}$ maximized at $59.12 \mathrm{~g} / \mathrm{L}$ at $55^{\circ} \mathrm{C}$. At $50^{\circ} \mathrm{C}$, the concentration of $\mathrm{IG}_{234}$ was $57.5 \mathrm{~g} / \mathrm{L}$. The statistical analysis shows that there was no significant difference in obtained concentration of $\mathrm{IG}_{234}$ in the two cases. Besides, due to economic aspect, the reaction temperature of $50^{\circ} \mathrm{C}$ was chosen as optimal value for SST reaction. Moreover, the data in Figure 3(b) also indicate that there was a considerable decrease in concentration of $\mathrm{IG}_{234}$ when the reaction temperatures were further risen. To be specific, the concentrations of $\mathrm{IG}_{234}$ were 40.82 , 29.74 , and $37.16 \mathrm{~g} / \mathrm{L}$, respectively, at $60^{\circ} \mathrm{C}, 65^{\circ} \mathrm{C}$, and $70^{\circ} \mathrm{C}$. The results of this study clearly showed that range of optimal $\mathrm{pH}$ and reaction temperature had good agreement with the manufacturer's instructions. Besides, the findings were similar to results reported by Niu et al. [4]. Specifically, the study showed that all three enzymes of $\beta$-amylase, pullulanase, and transglucosidase obtained from similar biological sources exhibited over $50 \%$ of their maximum activity at $\mathrm{pH}$ from 5.0 to 6.0 and reaction temperature from 45 to $65^{\circ} \mathrm{C}$.
3.3. Effects of Dosages of Various Enzymes on SST for the Synthesis of IMOs. As is known, the barley $\beta$-amylase only released sequentially maltose from the nonreducing ends of the starch polymers [9]. To determine effect of dosage of $\beta$-amylase on the synthesis of IMOs, different dosages of $\beta$-amylase were added to the SST reaction. Meanwhile pullulanase and transglucosidase were used in all experiments at dosages of $0.6 \mathrm{U} / \mathrm{g}$ and $15 \mathrm{U} / \mathrm{g}$, respectively, at $\mathrm{pH}$ of 5.0 and reaction time of $12 \mathrm{~h}$. The achieved data are demonstrated in Table 2.

What stands out from data in Table 2 is that when the dosage of $\beta$-amylase increased from $1.0 \mathrm{U} / \mathrm{g}$ to $3.0 \mathrm{U} / \mathrm{g}$, the $\mathrm{IG}_{234}$ concentration increased from 58.66 to $63.65 \mathrm{~g} / \mathrm{L}$, respectively. The highest $\mathrm{IG}_{234}$ concentration reached $63.65 \mathrm{~g} / \mathrm{l}$ at $\beta$-amylase dosage of $3.0 \mathrm{U} / \mathrm{g}$. However, a further increase in $\beta$-amylase dosages led to a drop in the concentrations of $\mathrm{IG}_{234}$. To be specific, the concentration of $\mathrm{IG}_{234}$ achieved $62.76 \mathrm{~g} / \mathrm{L}$ and $57.09 \mathrm{~g} / \mathrm{L}$ at $\beta$-amylase dosages of 4.0 and $5.0 \mathrm{U} / \mathrm{g}$, respectively. The results showed that there existed an optimal dosage of $\beta$-amylase in SST reaction for production of IMOs from SPS. These results can be explained as follows: when the dosage of $\beta$-amylase was increased to a certain level, the formation of IMOs was increased because the enzyme $\beta$-amylase enhanced production of more maltose and maltotriose in the SST reaction mixture. This led to enhancement of production of IMOs by transglucosidase [9]. Moreover, the presence of $\beta$-amylase in SST reaction also catalyzed for hydrolysis of maltodextrin to form maltooligosaccharide, an essential substrate for synthesis of IMOs [25].

Besides, the statistical analysis indicates that there was a good correlation between the concentrations of $\mathrm{IG}_{234}$ when adding $\beta$-amylase dosages of $2.0 \mathrm{U} / \mathrm{g}, 3.0 \mathrm{U} / \mathrm{g}$, and $4.0 \mathrm{U} / \mathrm{g}$. Nevertheless, there was a better correlation in case of using $\beta$-amylase dosage of $2.0 \mathrm{U} / g$ compared with $1.0 \mathrm{U} / \mathrm{g}$. Similarly, the $\beta$-amylase dosage of $4.0 \mathrm{U} / \mathrm{g}$ gave closer correlation than those of cases of $2.0 \mathrm{U} / \mathrm{g}$ and $3.0 \mathrm{U} / \mathrm{g}$ of applied $\beta$-amylase dosages. Derived from the results and discussed as aforementioned, the $\beta$-amylase dosage of $3.0 \mathrm{U} / \mathrm{g}$ was chosen 
TABLE 2: Effect of dosages of various enzymes on SST for the synthesis of IMOs.

\begin{tabular}{lc}
\hline Dosage of the enzyme & Concentration of $\mathrm{IG}_{234}(\mathrm{~g} / \mathrm{L})$ \\
\hline$\beta$-Amylase $(\mathrm{U} / g)$ & $58.66 \pm 0.63^{\mathrm{ab}}$ \\
1.0 & $60.70 \pm 0.87^{\mathrm{abc}}$ \\
2.0 & $63.65 \pm 2.99^{\mathrm{c}}$ \\
3.0 & $62.76 \pm 1.54^{\mathrm{bc}}$ \\
4.0 & $57.09 \pm 1.02^{\mathrm{a}}$ \\
5.0 & \\
\hline Pullulanase $(\mathrm{U} / g)$ & $55.70 \pm 0.82^{\mathrm{a}}$ \\
0.2 & $59.87 \pm 0.64^{\mathrm{b}}$ \\
0.4 & $61.82 \pm 1.86^{\mathrm{b}}$ \\
0.6 & $69.24 \pm 1.91^{\mathrm{c}}$ \\
0.8 & $67.20 \pm 0.98^{\mathrm{c}}$ \\
1.0 & \\
\hline Transglucosidase $(\mathrm{U} / g)$ & $60.84 \pm 0.33^{\mathrm{c}}$ \\
3 & $64.78 \pm 0.89^{\mathrm{d}}$ \\
5 & $67.37 \pm 0.64^{\mathrm{e}}$ \\
10 & $65.40 \pm 1.42^{\mathrm{de}}$ \\
15 & $62.00 \pm 0.98^{\mathrm{c}}$ \\
20 & $57.44 \pm 1.46^{\mathrm{b}}$ \\
30 & $53.47 \pm 0.79^{\mathrm{a}}$ \\
\hline
\end{tabular}

Values are mean \pm standard deviation of duplicate analyses. Values followed by the same letter in the same column were not significantly different at $p=0.05$.

as the optimal value for the SST reaction to synthesize the IMOs from SPS.

In this study, the pullulanase enzyme was also selected to be added to SST reaction for synthesis of IMOs from SPS. The pullulanase is an enzyme that specifically hydrolyzes $\alpha$-1,6-linkages in starch molecules [40]. Pullulanase has proved the remarkably increase of the IMOs yield which had no harmful effects on IMOs quality [4]. This can be explained as follows: the pullulanase requires each of the two chains linked by an $\alpha-1,6$-glycosidic bond containing at least two $\alpha$-1,4-linked glucose units. Thus, the smallest substrate for pullulanase is the tetrasaccharide $6^{2}$ - $\alpha$-maltosylmaltose [28]. Meanwhile, the main products formed due to the transglucosidase enzyme activity have no such structural form. To determine effect of adding the pullulanase on production of IMOs by SST reaction from SPS, the different amounts of pullulanase M2 were supplemented into the reaction. The dosages of both $\beta$-amylase and transglucosidase were $3.0 \mathrm{U} / \mathrm{g}$ and $15.0 \mathrm{U} / \mathrm{g}$, respectively, which were simultaneously added to the SST reaction. The solution $\mathrm{pH}$ and reaction time were maintained at 5 and $12 \mathrm{~h}$, respectively. The obtained results are shown in Table 2. As can be seen from data in Table 2, the concentration of $\mathrm{IG}_{234}$ saw a significant increase when the pullulanase dosage was increased from $0.2 \mathrm{U} / \mathrm{g}$ to $0.8 \mathrm{U} / \mathrm{g}$ and peaked at $0.8 \mathrm{U} / \mathrm{g}$ with $69.24 \mathrm{~g} / \mathrm{L}$ of $\mathrm{IG}_{234}$. However, a further growth in pullulanase dosage led to a slight decrease in the concentration of $\mathrm{IG}_{234}$ with $67.2 \mathrm{~g} / \mathrm{L}$ at $1.0 \mathrm{U} / \mathrm{g}$ of pullulanase dosage. These results were because the pullulanase enhanced hydrolysis of $\alpha-1,6-$ linkages in starch molecules [28]. In particular, the combination between pullulanase and $\beta$-amylase at a suitable ratio in the same SST reaction condition proved the promoting generation of more short chain maltose and maltodextrin which resulted in improving the synthesis performance of IMOs [1,7]. Besides, the HPLC analysis data also showed that application of the pullulanase for treatment of IMOs product had no negligible effects on the quality of IMOs. In particular, the pullulanase did not mostly hydrolyze $\alpha$-1,6-glycosidic linkings in the product mixtures [4]. Moreover, statistical analysis also showed that the $\mathrm{IG}_{234}$ concentrations in the cases of $0.8 \mathrm{U} / \mathrm{g}$ and $1.0 \mathrm{U} / \mathrm{g}$ had similarities. Thus, the pullulanase content of $0.8 \mathrm{U} / \mathrm{g}$ was selected for the next experiments.

Together with $\beta$-amylase and pullulanase, transglucosidase was also added to the SST reaction of SPS for synthesis of IMOs. The effect of various dosages of transglucosidase on the IMOs formation was examined, and results are summarized in Table 2 . The $\mathrm{IG}_{234}$ concentrations gradually increased from $60.84 \mathrm{~g} / \mathrm{L}$ to $67.37 \mathrm{~g} / \mathrm{L}$ when the transglucosidase dosages were increased from $3.0 \mathrm{U} / \mathrm{g}$ to $10.0 \mathrm{U} / \mathrm{g}$. Meanwhile, the concentration of $\mathrm{IG}_{234}$ witnessed a gradual drop trend when the dosage of transglucosidase went to $30 \mathrm{U} / \mathrm{g}$. To be specific, the $\mathrm{IG}_{234}$ concentration decreased to $53.47 \mathrm{~g} / \mathrm{L}$ at transglucosidase dosage of $30 \mathrm{U} / \mathrm{g}$. This result can be explained based on transglucosidase properties. Because the transglucosidase can simultaneously hydrolyze both $\alpha$-1,4-glycosidic and $\alpha$-1,6-glycosidic linkings. However, the hydrolysis rate of $\alpha$-1,4-glycosidic linkings was more rapid than that of $\alpha-1,6$-glycosidic bonds by about twice [9]. As a result, when the transglucosidase concentration is high, the hydrolysis rate of oligosaccharide substrates is promoted, which leads to release of more undesirable free glucose molecules [32]. It causes a decrease in IMOs concentration. Furthermore, the formed IMOs products can also be hydrolyzed at high transglucosidase dosage in the SST reaction. Also, statistical analysis indicated that the transglucosidase enzyme dosages of $10.0 \mathrm{U} / \mathrm{g}$ and $15.0 \mathrm{U} / \mathrm{g}$ gave the same $\mathrm{IG}_{234}$ concentration. Thus, derived from the economic aspect, the transglucosidase dosage of $10.0 \mathrm{U} / \mathrm{g}$ was chosen for the following experiments.

In summary, the experiment to investigate effect of dosages of various enzymes on simultaneous saccharification and transglycosylation for synthesis of IMOs chose the optimal values of enzymes dosages for SST reaction to produce IMOs from SPS. These optimal dosages were $3.0 \mathrm{U} /$ $\mathrm{g}, 0.8 \mathrm{U} / \mathrm{g}$, and $10.0 \mathrm{U} / \mathrm{g}$, respectively, for $\beta$-amylase, pullulanase, and transglucosidase.

\subsection{Effects of Reaction Time on SSTfor the Synthesis of IMOs.} The experiment to study effect of reaction time on the liquefied liquid was conducted at $\mathrm{pH}$ of 5.0 , reaction temperature of $50^{\circ} \mathrm{C}$, and dosages of $\beta$-amylase of $3.0 \mathrm{U} / \mathrm{g}$, pullulanase of $0.8 \mathrm{U} / \mathrm{g}$, and transglucosidase of $10 \mathrm{U} / \mathrm{g}$ with varying of reaction time between $6 \mathrm{~h}$ and $48 \mathrm{~h}$. The experimental results are highlighted in Figure 4.

What stands out from data in Figure 4 is that there was a marginal increase in the concentration of individual IGs $\left(\mathrm{IG}_{2}-\mathrm{IG}_{4}\right)$ with an increase in the reaction time from $6 \mathrm{~h}$ to $48 \mathrm{~h}$. Also, total concentration of $\mathrm{IG}_{234}$ saw a corresponding increase. Specifically, the $\mathrm{IG}_{234}$ concentration was increased 


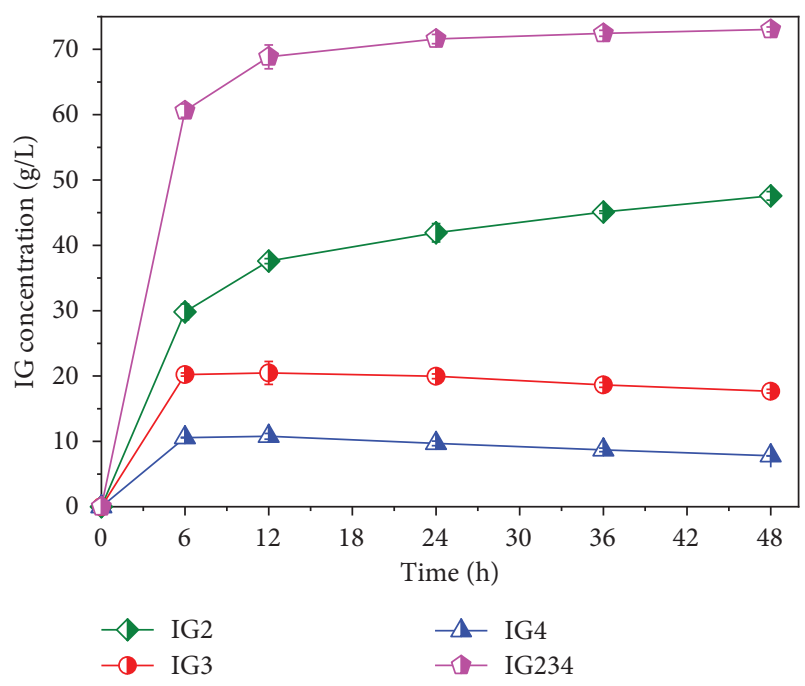

FIGURE 4: Effects of reaction time on IMO formation during simultaneous saccharification and transglycosylation.

from $60.61 \mathrm{~g} / \mathrm{L}$ to $68.85 \mathrm{~g} / \mathrm{L}$ with an increase in reaction time from $6 \mathrm{~h}$ to $12 \mathrm{~h}$, respectively. This trend had no negligible change at the reaction time between $12 \mathrm{~h}$ and $48 \mathrm{~h}$. This was due to the ability of transglucosidase enzyme in directly using the formed IMOs as substrates to hydrolyze them into other by-products [4]. As mentioned above, the transglucosidase can hydrolyze both the $\alpha$-1,4-glycosidic and $\alpha$-1,6-glycosidic bonds and the hydrolysis reaction rate of $\alpha$-1,4-glycosidic bond is quicker than hydrolysis reaction rate of glycosidic $\alpha$-1,6-bond by twice [9]. Therefore, the SST reaction required the optimal time period to reach a maximum synthesis performance of IMOs from SPS. Besides, the number of $\alpha$-1,4-glycosidic bonds in the hydrolyzed liquid saw a downward trend, while the number of $\alpha$-1,6-glycosidic bonds was gradually increased; and when the number of $\alpha$-1,4-glycosidic bonds was decreased to a low level and the $\alpha$-1,6-glycosidic linkings were increased to an equilibrium level, the $\mathrm{IG}_{234}$ content only increased slightly followed by a decrease trend in the $\mathrm{IG}_{234}$ content.

In this study, the concentration of $\mathrm{IG}_{234}$ formed after $12 \mathrm{~h}$ was $68.85 \mathrm{~g} / \mathrm{L}$, which was not much lower than that of $24 \mathrm{~h}$ with an $\mathrm{IG}_{234}$ concentration of $71.58 \mathrm{~g} / \mathrm{L}$. Moreover, the contents of $\mathrm{IG}_{3}$ and $\mathrm{IG}_{4}$ tended to decrease with an increase in reaction time from $24 \mathrm{~h}$ to $48 \mathrm{~h}$. Besides, both $\mathrm{IG}_{3}$ and $\mathrm{IG}_{4}$ are considered as difficult or undigested IMOs by the human's enzyme system [9]. The statistical analysis also indicates that there was a significant difference in the concentration of $\mathrm{IG}_{234}$ formed after $12 \mathrm{~h}$ reaction time compared to other cases. At reaction time of $24 \mathrm{~h}, 36 \mathrm{~h}$, and $48 \mathrm{~h}$, the contents of formed $\mathrm{IG}_{234}$ had no significant difference at $p=0.05$. Therefore, the most suitable time for the SST reaction to synthesize IMOs from the SPS was $12 \mathrm{~h}$. Comparing the results obtained in this study about the gained IMOs concentrations with other studies which used conventional methods for production of IMOs showed that IMOs concentrations obtained in recent work were higher those of other studies at the same reaction time period. To be specific, the maximum IMOs concentration that was obtained from liquefaction of the banana starch by Termamyl SC, barley $\beta$-amylase, and transglucosidase L enzyme in saccharification and transglycosylation reactions was $70.74 \pm 4.09 \mathrm{~g} / \mathrm{l}$ after $24 \mathrm{~h}$ of saccharification and 12 hours of transglycosylation [9]. It is clear that total reaction time for two separate steps of saccharification and transglycosylation was $36 \mathrm{~h}$, which was much higher than that of this study. Thus, the simultaneous combination of $\beta$-amylase, pullulanase, and transglucosidase activities in simultaneous saccharification and transglycosylation reaction of SPS for synthesis of IMOs shortens reaction time by three times compared with other studies with the same concentration of IMOs.

\section{Conclusions}

In this study, a two-step synthesis procedure of IMOs from sweet potato starch was successfully developed. Investigation of factors affecting the liquefaction and simultaneous saccharification and transglycosylation reactions chose the most suitable conditions for production of IMOs from inexpensive and abundant SPS source. In the liquefaction, the Spezyme Xtra enzyme preparation gave the highest content of oligosaccharides components. The optimal conditions for liquefaction reaction of SPS to synthesize IMOs were at SPS slurry of $25 \%, \alpha$-amylase dosage of $1.0 \mathrm{CU} / \mathrm{g}$, and $\mathrm{pH}$ of 5.8 at $80^{\circ} \mathrm{C}$ for $30 \mathrm{~min}$ of reaction time. At this condition, the compositions of oligosaccharides reached $73.95 \pm 0.02 \%$ $(\mathrm{w} / \mathrm{w})$ for $\mathrm{G}_{1}-\mathrm{G}_{10}$ and $49.24 \pm 3.19 \%(\mathrm{w} / \mathrm{w})$ for $\mathrm{G}_{1}-\mathrm{G}_{6}$. In the simultaneous saccharification and transglycosylation reaction, the highest concentration of IMOs was achieved as $68.85 \pm 1.82 \mathrm{~g} / \mathrm{L}$ at optimal operational conditions, including $\mathrm{pH}$ of $5.0, \beta$-amylase dosage of $3.0 \mathrm{U} / \mathrm{g}$, pullulanase dosage of $0.8 \mathrm{U} / \mathrm{g}$, and transglucosidase dosage of $10.0 \mathrm{U} / \mathrm{g}$ at $50^{\circ} \mathrm{C}$ for $12 \mathrm{~h}$ reaction time. In particular, the synthesis procedure of IMOs applied simultaneous saccharification and transglycosylation shortens the reaction time of SST step for synthesis of IMOs from SPS by three times. The purification of raw IMOs using Saccharomyces cerevisiae var. diastaticus BE 134 was also improved. In conclusion, the synthesis procedure of IMOs derived from SPS sources was feasible to apply in practice to produce useful prebiotics. In our next studies, it is necessary to further investigate the IMOs' structure in the finished products and the application of supplement of IMOs into food products also needs further study.

\section{Data Availability}

The data used to support the findings of this study are included within the article and supplementary materials.

\section{Additional Points}

(i) Isomaltooligosaccharide (IMO) was synthesized from low-cost sweet potato starch (SPS). (ii) The optimal condition for the SST reaction of SPS was systematically studied. (iii) The SST reaction of SPS to synthesize IMOs shortens 
reaction time by three times. (iv) The yeast cells were applied to purify IMO products from SPS.

\section{Conflicts of Interest}

The authors declare no conflicts of interest.

\section{Supplementary Materials}

Supplemental Figure S1: TLC graphs of IMOs: (a) separation of sugars by TLC and (b) testing the presence of glucose, maltose, and maltotriose in IMO solution after treatment with yeast cells Saccharomyces cerevisiae var. diastaticus BE 134 by TLC using a solvent mixture including $n$-butanol: isopropanol: water at a ratio of $50: 25: 20(\mathrm{v} / \mathrm{v} / \mathrm{v})$. Supplemental Figures S2-S5: HPLC graphs of $\alpha$-amylase enzyme preparations, IMOs at various $\mathrm{pH}$ values and temperatures, IMOs at dosages of various enzymes, and IMOs at various contact times, respectively. Testing the presence of glucose, maltose, and maltotriose in IMO slurry after being treated with yeast cells Saccharomyces cerevisiae var. diastaticus BE 134 by TLC using a solvent mixture of n-butanol: isopropanol: water at a ratio of $50: 25: 20(\mathrm{v} / \mathrm{v} / \mathrm{v})$. The results show that the glucose, maltose, and maltotriose concentrations gradually decreased to lower concentrations than those of the standard samples prepared at low concentrations. (Supplementary Materials)

\section{References}

[1] Y.-C. Pan and W.-C. Lee, "Production of high-purity isomalto-oligosaccharides syrup by the enzymatic conversion of transglucosidase and fermentation of yeast cells," Biotechnology and Bioengineering, vol. 89, no. 7, pp. 797-804, 2005.

[2] J. Yun, J.-H. Suh, and S.-K. Song, "Kinetic study and mathematical model for the production of isomalto-oligosaccharides from maltose by transglycosylation of Aureobasidium pullulans," Korean Chemical Engineering Research, vol. 32, 1994.

[3] D. Goffin, N. Delzenne, C. Blecker, E. Hanon, C. Deroanne, and M. Paquot, "Will isomalto-oligosaccharides, a wellestablished functional food in Asia, break through the European and American market? The status of knowledge on these prebiotics," Critical Reviews in Food Science and Nutrition, vol. 51, no. 5, pp. 394-409, 2011.

[4] D. Niu, J. Qiao, P. Li et al., "Highly efficient enzymatic preparation of isomalto-oligosaccharides from starch using an enzyme cocktail," Electronic Journal of Biotechnology, vol. 26, pp. 46-51, 2017.

[5] A. Ketabi, L. A. Dieleman, and M. G. Gänzle, "Influence of isomalto-oligosaccharides on intestinal microbiota in rats," Journal of Applied Microbiology, vol. 110, no. 5, pp. 1297-1306, 2011.

[6] Y. Hu, A. Ketabi, A. Buchko, and M. G. Gänzle, "Metabolism of isomalto-oligosaccharides by Lactobacillus reuteri and bifidobacteria," Letters in Applied Microbiology, vol. 57, no. 2, pp. 108-114, 2013.

[7] J. Cui, Y. Li, Q. Wang et al., "Production, purification and analysis of the isomalto-oligosaccharides from Chinese chestnut (Castanea mollissima Blume) and the prebiotics effects of them on proliferation of Lactobacillus," Food and Bioproducts Processing, vol. 106, pp. 75-81, 2017.
[8] C. Berrocal, H. Chico, E. Carranza, and R. Vega, "Desirability function for optimization of the synthesis of high-panose isomaltooligosaccharides from maltose catalyzed by a novel commercial enzyme preparation from Aspergillus niger," Biochemical Engineering Journal, vol. 171, Article ID 108003, 2021.

[9] S. Chockchaisawasdee and N. Poosaran, "Production of isomaltooligosaccharides from banana flour," Journal of the Science of Food and Agriculture, vol. 93, no. 1, pp. 180-186, 2013.

[10] Q. Gu, Y. Yang, G. Jiang, and G. Chang, "Study on the regulative effect of isomaltooligosaccharides on human intestinal flora," Journal of Hygiene Research, vol. 32, pp. 54-55, 2003.

[11] T. Kaneko, T. Kohmoto, H. Kikuchi et al., "Effects of isomaltooligosaccharides intake on defecation and intestinal environment in healthy volunteers," Journal of Home Economics of Japan, vol. 44, pp. 245-254, 1993.

[12] T. Kaneko, T. Kohmoto, H. Kikuchi, M. Shiota, H. Iino, and T. Mitsuoka, "Effects of isomaltooligosaccharides with different degrees of polymerization on human fecal bifidobactcria," Bioscience, Biotechnology, and Biochemistry, vol. 58, no. 12, pp. 2288-2290, 1994.

[13] T. Kohmoto, F. Fukui, H. Takaku, and T. Mitsuoka, "Doseresponse test of isomaltooligosaccharides for increasing fecal bifidobacteria," Agricultural and Biological Chemistry, vol. 55, no. 8, pp. 2157-2159, 1991.

[14] T. Kohmoto, F. Fukui, H. Takaku, Y. Machida, M. Arai, and T. Mitsuoka, "Effect of isomalto-oligosaccharides on human fecal flora," Bifidobacteria and Microflora, vol. 7, no. 2, pp. 61-69, 1988.

[15] S. Ge, D.-L. Cai, and L.-L. Wan, "Determination of glycemic index of xylitol and isooligosaccharide," Chinese Journal of Clinical Nutrition, vol. 14, pp. 235-237, 2006.

[16] H.-F. Wang, P.-S. Lim, M.-D. Kao, E.-C. Chan, L.-C. Lin, and N.-P. Wang, "Use of isomalto-oligosaccharide in the treatment of lipid profiles and constipation in hemodialysis patients," Journal of Renal Nutrition, vol. 11, no. 2, pp. 73-79, 2001.

[17] H.-L. Chen, Y.-H. Lu, J.-J. Lin, and L.-Y. Ko, "Effects of isomalto-oligosaccharides on bowel functions and indicators of nutritional status in constipated elderly men," Journal of the American College of Nutrition, vol. 20, no. 1, pp. 44-49, 2001.

[18] H. Takaku, "Anomalously linked oligosaccharides mixture," Handbook of Amylases and Related Enzymes: Their Sources, Isolation Methods, pp. 215-217, Pergamon Press, New York, NY, USA, 1988.

[19] M. Tanaka, K. Ishiguro, T. Oki, and S. Okuno, "Functional components in sweet potato and their genetic improvement," Breeding Science, vol. 67, no. 1, pp. 52-61, 2017.

[20] J. W. Yun, M. G. Lee, and S. K. Song, "Continuous production of isomalto-oligosaccharides from maltose syrup by immobilized cells of permeabilized Aureobasidium pullulans," Biotechnology Letters, vol. 16, no. 11, pp. 1145-1150, 1994.

[21] K. J. Duan, D. C. Sheu, M. T. Lin, and H. C. Hsueh, "Reaction mechanism of isomaltooligosaccharides synthesis by $\alpha$-glucosidase from Aspergillus carbonarious," Biotechnology Letters, vol. 16, no. 11, pp. 1151-1156, 1994.

[22] B.-R. Park, J. Y. Park, S. H. Lee et al., "Synthesis of improved long-chain isomaltooligosaccharide, using a novel glucosyltransferase derived from Thermoanaerobacter thermocopriae, with maltodextrin," Enzyme and Microbial Technology, vol. 147, Article ID 109788, 2021.

[23] N. Kato, S. Suyama, M. Shirokane, M. Kato, T. Kobayashi, and N. Tsukagoshi, "Novel $\alpha$-glucosidase from Aspergillus 
nidulans with strong transglycosylation activity," Applied and Environmental Microbiology, vol. 68, no. 3, pp. 1250-1256, 2002.

[24] T. Kuriki, M. Yanase, H. Takata, Y. Takesada, T. Imanaka, and S. Okada, "A new way of producing isomalto-oligosaccharide syrup by using the transglycosylation reaction of neopullulanase," Applied and Environmental Microbiology, vol. 59, no. 4, pp. 953-959, 1993.

[25] W. Sorndech, D. Sagnelli, A. Blennow, and S. Tongta, "Combination of amylase and transferase catalysis to improve IMO compositions and productivity," LWT-Food Science and Technology, vol. 79, pp. 479-486, 2017.

[26] A. K. Goulas, D. A. Fisher, G. K. Grimble, A. S. Grandison, and R. A. Rastall, "Synthesis of isomaltooligosaccharides and oligodextrans by the combined use of dextransucrase and dextranase," Enzyme and Microbial Technology, vol. 35, no. 4, pp. 327-338, 2004.

[27] A. Basu, S. Mutturi, and S. G. Prapulla, "Production of isomaltooligosaccharides (IMO) using simultaneous saccharification and transglycosylation from starch and sustainable sources," Process Biochemistry, vol. 51, no. 10, pp. 1464-1471, 2016.

[28] S. L. Hii, J. S. Tan, T. C. Ling, and A. B. Ariff, "Pullulanase: role in starch hydrolysis and potential industrial applications," Enzyme Research, vol. 2012, Article ID 921362, 14 pages, 2012.

[29] A. Pascual-Maté, S. M. Osés, G. L. Marcazzan, S. Gardini, M. A. Fernández Muiño, and M. Teresa Sancho, "Sugar composition and sugar-related parameters of honeys from the northern Iberian Plateau," Journal of Food Composition and Analysis, vol. 74, pp. 34-43, 2018.

[30] O. Imo, Application for the Approval of Application for the Approval of Isomalto-Oligosaccharide, 2008.

[31] K. Hayakawa, K. Ando, N. Yoshida et al., "Determination of saccharides in sake by high-performance liquid chromatography with polarized photometric detection," Biomedical Chromatography, vol. 14, no. 2, pp. 72-76, 2000.

[32] P. Saman, C. Kuancha, A. Chaiongkarn, and S. Moonmangmee, "Isomalto-oligosaccharides production from rice flour and cassava starch," Journal of Food Science and Agricultural Technology, vol. 5, pp. 188-192, 2019.

[33] X. Liu, T. Deng, X. Liu et al., "Isomalto-oligosaccharides produced by endodextranase Shewanella sp. GZ-7 from sugarcane plants," Natural Product Communications, vol. 15, no. $9,2020$.

[34] FAO, FAO Statistics, FAO, Rome, Italy, 2019.

[35] M. Dubois, K. A. Gilles, J. K. Hamilton, P. A. Rebers, and F. Smith, "Colorimetric method for determination of sugars and related substances," Analytical Chemistry, vol. 28, no. 3, pp. 350-356, 1956.

[36] Megazyme, "Alpha-amylase assay procedure (ceralpha method) for the measurement of plant and microbial alphaamylases," Megazyme Data Book, pp. 1-20, 2012.

[37] Megazyme, "Beta-amylase assay procedure (betamyl-3 ${ }^{\circledR}$ method) for the measurement of plant and microbial betaamylases," Megazyme Data Book, vol. 18, 2018.

[38] Megazyme, "Assay of pullulanase using red-pullulan, S-Rpul 07/17," Megazyme Data Book, 2008.

[39] S. Chiba and T. Shimomura, "Thin-layer chromatography of oligosaccharides," Agricultural and Biological Chemistry, vol. 29, no. 5, pp. 486-487, 1965.

[40] T.-R. Yan and R.-D. Chiou, "Catalytic properties of a transglucosidase from Aspergillus niger CCRC 31494," Biotechnology Letters, vol. 18, no. 5, pp. 553-558, 1996. 